\title{
Iodine and Selenium Biofortification of Chervil Plants Treated with Silicon Nanoparticles
}

\author{
Nadezhda Golubkina ${ }^{1, *}$, Anastasia Moldovan ${ }^{1}$, Mikhail Fedotov ${ }^{2}$, Helene Kekina ${ }^{3}$, Viktor Kharchenko ${ }^{1}$, \\ Gundar Folmanis ${ }^{2}$, Andrey Alpatov ${ }^{2}$ and Gianluca Caruso ${ }^{4}$ \\ 1 Federal Scientific Vegetable Center, Moscow 143072, Russia; nastiamoldovan@mail.ru (A.M.); \\ kharchenkoviktor777@gmail.com (V.K.) \\ 2 A. Baikov Institute of Metallurgy and Material Science, Leninsky Pr. 49, Moscow 119334, Russia; \\ Mikle_fed@mail.ru (M.F.); folmimet@yandex.ru (G.F.); aaalpatov@imet.ac.ru (A.A.) \\ 3 Department of Hygiene, Medical Postgraduate Academy, Moscow 123995, Russia; lena.kekina@mail.ru \\ 4 Department of Agricultural Sciences, University of Naples Federico II, Portici, 80055 Naples, Italy; \\ gcaruso@unina.it \\ * Correspondence: segolubkina45@gmail.com
}

check for updates

Citation: Golubkina, N.; Moldovan,

A.; Fedotov, M.; Kekina, H.;

Kharchenko, V.; Folmanis, G.;

Alpatov, A.; Caruso, G. Iodine and

Selenium Biofortification of Chervil

Plants Treated with Silicon

Nanoparticles. Plants 2021, 10, 2528.

https://doi.org/10.3390/plants

10112528

Academic Editor: Georgia Ntatsi

Received: 5 November 2021

Accepted: 18 November 2021

Published: 20 November 2021

Publisher's Note: MDPI stays neutral with regard to jurisdictional claims in published maps and institutional affiliations.

Copyright: (c) 2021 by the authors. Licensee MDPI, Basel, Switzerland. This article is an open access article distributed under the terms and conditions of the Creative Commons Attribution (CC BY) license (https:// creativecommons.org/licenses/by/ $4.0 /)$.

\begin{abstract}
Production of functional food with high levels of selenium (Se) and iodine (I) obtained via plant biofortification shows significant difficulties due to the complex interaction between the two elements. Taking into account the known beneficial effect of silicon (Si) on plant growth and development, single and joint foliar biofortification of chervil plants with potassium iodide $\left(150 \mathrm{mg} \mathrm{L}^{-1}\right)$ and sodium selenate $\left(10 \mathrm{mg} \mathrm{L}^{-1}\right)$ was carried out in a pot experiment with and without Si nanoparticles foliar supplementation. Compared to control plants, nano-Si $\left(14 \mathrm{mg} \mathrm{L}^{-1}\right)$ increased shoot biomass in all treatments: by 4.8 times with $\mathrm{Si}$; by 2.8 times with $\mathrm{I}+\mathrm{Si}$; by 5.6 times with $\mathrm{Se}+\mathrm{Si}$; by 4.0 times with $\mathrm{I}+\mathrm{Se}+\mathrm{Si}$. The correspondent increases in root biomass were 4.5, 8.7, 13.3 and 10.0 times, respectively. The growth stimulation effect of Se, I and I + Se treatments resulted in a 2.7, 3.5 and 3.6 times increase for chervil shoots and 1.6, 3.1 and 8.6 times for roots, respectively. Nano-Si improved I biofortification levels by twice, while I and Se enhanced the plant content of each other. All treatments decreased nitrate levels, compared to control, and increased the photopigment accumulation. Improvement of total antioxidant activity and phenolic content was recorded only under the joint application of Se $+\mathrm{I}+\mathrm{Si}$. Foliar nano-Si treatment affected other element content in plants: decreased $\mathrm{Na}^{+}$accumulation in single and joint supplementation with Se and I, restored $\mathrm{Fe}$, $\mathrm{Mn}$ and $\mathrm{Cr}$ amount compared to the decreased levels recorded in separately Se and I fortified plants and promoted $\mathrm{Al}$ accumulation both with or without Se and I biofortification. The results of this research suggest high prospects of foliar nano-Si supply for enhancing both growth and joint I/Se biofortification of chervil.
\end{abstract}

Keywords: Anthriscus cerefolium L. Hoffm.; Se-I biofortification; Si nanoparticles; antioxidants; mineral elements

\section{Introduction}

Among the micro-elements which are essential for human beings and beneficial for plants, selenium (Se) and iodine (I) have special importance, mainly for their participation in the growth and development of all living beings, antioxidant properties, immunity optimization and protection against biotic and abiotic stresses [1]. Iodine (I) and Se deficiency are common in many worldwide areas, increasing the risk of viral (including COVID-19), oncological and cardiovascular diseases, negatively affecting fertility and restricting cognitive abilities [2-4]. Both Se and I are components of 3-iodothyronine deiodinases, thus taking an active part in thyroid hormones production and functioning $[2,5,6]$. The adequate consumption levels of Se and I are $70 \mu \mathrm{g}$ and $150 \mu \mathrm{g}$ per day respectively [4,7].

The importance of Se and I for human health and the close relationship of their metabolism stimulate the development of agrochemical joint biofortification of plants with 
these elements [1]. The micro-elements Se and I demonstrate growth stimulating properties in plants, but the range of their beneficial effect is rather narrow and specific for each species, which causes serious problems in the industrial application of the biofortification method [1]. However, low doses of Se fertilizers in a national Finnish experiment [8] revealed high possibilities of such an approach in optimizing human Se status.

To improve the efficiency of joint Se-I biofortification, phytohormones (salicylic acid [9]) and arbuscular mycorrhizal fungi [10] were applied, while vanadium (V) was proposed for increasing I accumulation in plants $[1,11]$. Such approaches provided moderate improvement of plant growth and a relatively moderate increase in I levels due to the sensitivity of most plants to the toxic effect of a high I dose.

In recent years, the interest in silicon $(\mathrm{Si})$ application to agricultural crop productions has been increasing. Similarly to Se and I, both bulk and nano-Si are able to improve plant resistance to different forms of oxidant stress, stimulate growth, improve soil nutrient availability, plant antioxidant status [12-14], and participate in the transpiration process [15]. The small size of Si nanoparticles and immense surface area reportedly provide higher potential in agricultural application than bulk silicon for improved stress tolerance, nutrient accumulation, and plant growth [13]. These facts indicate possible prospects of nano-silicon application in Se and I biofortification processes. The improvement of rice growth due to foliar Se and Si nanoparticles supplementation under salinity stress [12], as well as the beneficial effect of these elements on the production of other plant species [16-19], provides the basis for investigating further opportunities in this direction. Restricted data regarding the efficiency of foliar nano-Si supplementation [19-22], scant information on the mechanism of the Se-Si relationship [23], and lack of information relevant to the I-Si interaction, especially the nano-Si effect, suggest the need to appropriately investigate the interaction peculiarities between these elements.

The present work aimed to evaluate the efficiency of chervil plant biofortification with Se and I under foliar nano-Si supply and the effects of these micro-elements on plant biochemical characteristics and elemental composition. Chervil (Anthriscus cerefolium (L.) Hoffm.) belongs to the Apiaceae family and is considered an exclusive spice with a short vegetation period, and remarkable medicinal properties and antioxidant content [24].

\section{Results and Discussion}

To evaluate the relationship between Se, I and nano-Si in chervil, nano-Si, sodium selenate and potassium iodide solutions were supplied through foliar applications, taking into account that this approach allows for minimizing the effect of soil characteristics on the interactions between the aforementioned elements. Besides, foliar biofortification is reportedly beneficial for supplying I to leafy crops [25] and is widely used for Se biofortification [26]. Among Se chemical forms used for plant biofortification, sodium selenate $\left(\mathrm{Se}^{+6}\right)$ was chosen because more mobile and less toxic compared to selenite form $\left(\mathrm{Se}^{+4}\right)$. Previous reports related to the high efficiency of nano-Si foliar application [21] set up the basis of nano-Si application in Se/I biofortification of chervil.

\subsection{Biometrical Parameters, Dry Matter and Nitrates}

Separate and joint foliar application of Se and I at concentrations of $10 \mathrm{mg} \mathrm{L}^{-1}$ and $150 \mathrm{mg} \mathrm{L}^{-1}$, respectively, were beneficial for chervil growth, with remarkable increases in shoot and root biomass (Table 1). The data reported in Table 1 indicate higher shoot/root biomass under I supplementation compared to Se application (3.4-3.5 and 2.7 times increase in shoots and 3.1 and 1.6 times increase in root biomass, respectively). Interestingly, higher concentrations of sodium selenate applied to plants in our previous research $(25,50$, $75 \mathrm{mg} \mathrm{L}^{-1}$ compared to $10 \mathrm{mg} \mathrm{L}^{-1}$ in the present work) did not improve chervil growth [27], thus suggesting the higher effectiveness of low Se doses to Anthriscus cerefolium L. 
Table 1. Yield, dry matter, and biometrical parameters of chervil under Se, I and Si supplementation.

\begin{tabular}{|c|c|c|c|c|c|c|}
\hline \multirow[t]{2}{*}{ Treatment } & \multicolumn{2}{|c|}{ Length $(\mathrm{cm})$} & \multicolumn{2}{|c|}{ Yield $\left(\mathrm{g} \cdot \mathrm{m}^{-2}\right)$} & \multicolumn{2}{|c|}{ Dry Matter (\%) } \\
\hline & Shoots & Roots & Shoots & Roots & Shoots & Roots \\
\hline Control & $18 \pm 2 c$ & $12 \pm 1 b$ & $470.4 \pm 47.0 \mathrm{e}$ & $33.6 \pm 3.4 \mathrm{~g}$ & $7.6 \pm 0.8 b$ & $7.3 \pm 0.7 c$ \\
\hline Se & $18 \pm 2 c$ & $12 \pm 1 b$ & $1283.2 \pm 128.3 \mathrm{~d}$ & $54.4 \pm 5.4 \mathrm{f}$ & $8.8 \pm 0.9 \mathrm{ab}$ & $10.9 \pm 1.1 \mathrm{ab}$ \\
\hline I & $20 \pm 2 b c$ & $13 \pm 1 b$ & $1622.4 \pm 162.1 \mathrm{c}$ & $105.6 \pm 10.6 \mathrm{e}$ & $8.3 \pm 0.8 \mathrm{ab}$ & $7.4 \pm 0.7 c$ \\
\hline $\mathrm{Se}+\mathrm{I}$ & $21 \pm 2 \mathrm{abc}$ & $17 \pm 2 \mathrm{a}$ & $1672.0 \pm 167.0 \mathrm{c}$ & $288.0 \pm 28.8 \mathrm{c}$ & $9.6 \pm 0.9 \mathrm{a}$ & $10.0 \pm 1.0 \mathrm{ab}$ \\
\hline $\mathrm{Si}$ & $20 \pm 2 b c$ & $17 \pm 2 \mathrm{a}$ & $2278.4 \pm 228.0 \mathrm{~b}$ & $192.0 \pm 19.2 \mathrm{~d}$ & $7.8 \pm 0.8 b$ & $8.5 \pm 0.9 \mathrm{bc}$ \\
\hline $\mathrm{Si}+\mathrm{Se}$ & $22 \pm 2 \mathrm{ab}$ & $19 \pm 2 \mathrm{a}$ & $2622.4 \pm 262.0 \mathrm{ab}$ & $448.0 \pm 44.8 \mathrm{a}$ & $8.9 \pm 0.9 \mathrm{ab}$ & $9.5 \pm 0.9 b$ \\
\hline $\mathrm{Si}+\mathrm{I}$ & $25 \pm 3 \mathrm{a}$ & $20 \pm 2 \mathrm{a}$ & $2928.0 \pm 292.8 \mathrm{a}$ & $404.8 \pm 40.4 \mathrm{ab}$ & $8.6 \pm 0.8 \mathrm{ab}$ & $9.3 \pm 0.9 b$ \\
\hline $\mathrm{Si}+\mathrm{I}+\mathrm{Se}$ & $22 \pm 2 \mathrm{ab}$ & $21 \pm 2 \mathrm{a}$ & $1851.2 \pm 185.0 \mathrm{c}$ & $336.0 \pm 33.6 \mathrm{bc}$ & $10.3 \pm 1.0 \mathrm{a}$ & $11.7 \pm 1.2 \mathrm{a}$ \\
\hline
\end{tabular}

Within each column, values with the same letters do not differ according to Duncan test at $p<0.05$.

In the present conditions of Se and I biofortification, foliar application of nano-Si gave additional benefits causing shoot and especially root growth stimulation (Figure 1), proving 8.2 and 3.8 times increase in root biomass of Se and I treated plants, respectively, and 2.0 and 1.8 times increase in shoot biomass, compared to plants treated separately with Se and I.
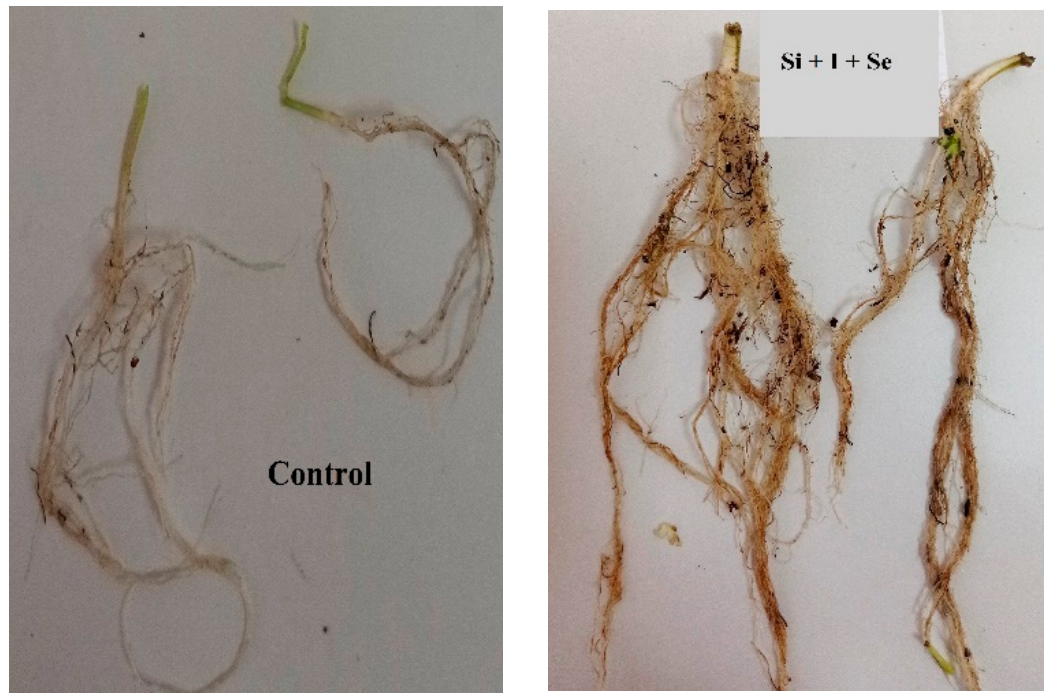

Figure 1. Root system of chervil under I, Se and Si treatments as compared to control.

Indeed, the mean increase in root length by 1.4 times was recorded upon foliar nano-Si application, while the shoot length in the same conditions increased only by 1.16 times. Nano-Si foliar application elicited a biomass increase in chervil by 4.8 times for shoots and 5.7 times for roots. The most pronounced increase in root biomass was recorded upon $\mathrm{Si}$ application in combination with Se and/or I, and reached 12 times increase under joint application of Si and I.

Neither Se, nor I or Si are considered essential for plants, but are able to stimulate their growth only in special conditions [28]. Chervil belongs to a group of Se non-accumulatorsplants, highly sensitive to Se toxicity, and therefore the growth stimulation effect is achieved mainly at low Se concentrations, capable to optimize water and nutrient supply and reduce oxidant stress [28].

A recent investigation of iodine role in plants revealed that the beneficial effect of $I$ supplementation may relate to the incorporation of I into plant proteins, thus affecting plant growth and development [29]. The latter outcome is in agreement with the revealed Se and I growth stimulation effect in chervil.

According to the literature reports, the beneficial effect of $\mathrm{Si}$ is recorded mainly under stress conditions, with great differences among different species, while in normal conditions 
Si supplementation has little or no effect [30]. Furthermore, previous findings indicate that Si may improve plant nutrition in non-stressed conditions [31]. Notably, the mentioned conclusions relate mainly to soil bulk $\mathrm{Si}$ application, while many fewer investigations were devoted to foliar nano-Si supply [22].

An increase in root and shoot biomass in conditions of Se and/or I biofortification, with or without nano-Si supply, indicates a lack of significant oxidant stress during plant growth and development, excluding the stress possibility connected with $\mathrm{Se}$, I or nano-Si application. The lack of significant changes in plant dry matter content in most treatments is consistent with the latter statement. On the other hand, we do not have enough information about interspecies differences in Se, I and nano-Si interaction under foliar application of these elements. Previous outcome regarding soil bulk $\mathrm{Si}$ supplementation suggests great differences in various species resistance to $\mathrm{Si}[28,31]$. Furthermore, the low concentration of nano-Si in the present study $\left(14 \mathrm{mg} \mathrm{L}^{-1}\right)$, compared to those described in the literature [12,21,32], entails that the detected growth stimulation effect is not directly connected with Si level increase in plant tissues but is of minor importance. To reveal the mechanism of the Si effect, additional comparative investigations are necessary for soil and foliar Se/I biofortification of different species under the application of both nano- and bulk Si.

Participation of Se, I and Si in nitrogen metabolism was recorded through nitrate accumulation levels (Figure 2). Lack of any nitrate level change in plants treated with I and a tendency of nitrate concentration to decrease under Se biofortification are in agreement both with previous observations of I biofortification of radish [33] and with studies of Se effect on nitrate reductase activity [34].



Figure 2. Effect of Si on nitrate accumulation in control chervil plants and plants fortified with I and/or Se. Values with the same letter do not differ statistically according to Duncan test at $p<0.05$.

Though both nano- and bulk Si are known to improve nitrogen uptake, assimilation, remobilization and induce amino acids biosynthesis under soil application [35-38], a significant decrease in nitrate accumulation in chervil treated with nano-Si, $\mathrm{Se}+$ nano-Si and $\mathrm{Se}+\mathrm{I}+$ nano-Si is the first observation of foliar nano-Si effect on nitrate metabolism. Lack of any effect of nano-Si on nitrate accumulation in chervil under I supply demonstrates a substantial different interaction between Se and nano-Si, and between I and nano-Si. In this respect, further investigations including a comparison between nano- and bulk $\mathrm{Si}$ treatments are needed to unveil peculiarities of Se-I-Si interaction. 


\subsection{Photosynthetic Pigments}

In the present experiment, single and joint biofortification of chervil with I and Se were characterized only by a tendency to the improvement of photosynthetic pigment synthesis. The non-significant effect of Se on photopigment biosynthesis may relate to the low applied concentration of this element. Indeed, the statistically significant beneficial effect of Se on chlorophyll and carotene accumulation in chervil leaves was previously recorded at concentrations equal to or higher than $50 \mathrm{mg} \mathrm{Se} \mathrm{L}^{-1}$ [27], proving the participation of Se in chlorophyll biosynthesis [39]. The effect of I on photosynthesis is not predictable, as previously reported $[40,41]$.

According to the literature, both soil and foliar application of nano-Si enhances the accumulation of photosynthetic pigments either under stress [13] or normal conditions of vegetation [21]. The present results are consistent with the latter observations indicating the predominant role of nano-Si treatment on photopigments' accumulation (Table 2). Indeed, the mean increase in total chlorophyll content in plants subjected to foliar nano-Si exceeds by $18 \%$ that recorded in chervil without application of Si.

Table 2. Photosynthetic pigments in chervil plants under Se, I and Si supplementation.

\begin{tabular}{|c|c|c|c|c|c|c|}
\hline Treatment & $\begin{array}{l}\text { Chlorophyll a } \\
\text { (mg g }{ }^{-1} \text { Fresh } \\
\text { Weight) }\end{array}$ & $\begin{array}{l}\text { Chlorophyll b } \\
\text { (mg g-1 Fresh } \\
\text { Weight) }\end{array}$ & $\begin{array}{c}\text { Total } \\
\text { Chlorophyll } \\
\text { (mg g }{ }^{-1} \text { Fresh } \\
\text { Weight) }\end{array}$ & Chl b/a Ratio & $\begin{array}{l}\text { Carotene } \\
\text { (mg g }{ }^{-1} \text { Fresh } \\
\text { Weight) }\end{array}$ & $\begin{array}{c}\text { Carotene:Chlorophyll } \\
\text { Ratio }\end{array}$ \\
\hline Control & $0.70 \pm 0.07 b$ & $1.77 \pm 0.18 b$ & $2.47 \pm 0.24 b$ & $2.53 \mathrm{a}$ & $0.38 \pm 0.04 b$ & $1: 6.66$ \\
\hline Se & $0.72 \pm 0.07 b$ & $1.98 \pm 0.19 \mathrm{ab}$ & $2.70 \pm 0.27 b$ & $2.75 \mathrm{a}$ & $0.43 \pm 0.04 \mathrm{ab}$ & $1: 6.58$ \\
\hline I & $0.71 \pm 0.07 b$ & $1.87 \pm 0.19 b$ & $2.58 \pm 0.25 b$ & $2.63 \mathrm{a}$ & $0.40 \pm 0.04 \mathrm{ab}$ & $1: 6.58$ \\
\hline $\mathrm{Se}+\mathrm{I}$ & $0.90 \pm 0.09 \mathrm{a}$ & $2.18 \pm 0.21 \mathrm{ab}$ & $3.08 \pm 0.31 \mathrm{ab}$ & $2.42 \mathrm{a}$ & $0.46 \pm 0.04 \mathrm{a}$ & $1: 5.26$ \\
\hline $\mathrm{Si}$ & $0.88 \pm 0.08 \mathrm{a}$ & $2.23 \pm 0.22 \mathrm{a}$ & $3.11 \pm 0.31 \mathrm{a}$ & $2.53 \mathrm{a}$ & $0.48 \pm 0.05 a$ & $1: 5.27$ \\
\hline $\mathrm{Si}+\mathrm{Se}$ & $0.96 \pm 0.09 a$ & $2.34 \pm 0.23 \mathrm{a}$ & $3.30 \pm 0.33 a$ & $2.44 \mathrm{a}$ & $0.48 \pm 0.05 a$ & $1: 5.08$ \\
\hline $\mathrm{Si}+\mathrm{I}$ & $0.83 \pm 0.08 \mathrm{ab}$ & $2.39 \pm 0.23 \mathrm{a}$ & $3.22 \pm 0.32 \mathrm{a}$ & $2.88 \mathrm{a}$ & $0.43 \pm 0.04 \mathrm{ab}$ & $1: 6.70$ \\
\hline $\mathrm{Si}+\mathrm{Se}+\mathrm{I}$ & $0.83 \pm 0.08 \mathrm{ab}$ & $2.29 \pm 0.22 \mathrm{a}$ & $3.12 \pm 0.31 \mathrm{a}$ & $2.76 \mathrm{a}$ & $0.49 \pm 0.05 a$ & $1: 5.63$ \\
\hline
\end{tabular}

Within each column, values with the same letters do not differ according to Duncan test at $p<0.05$.

\subsection{Total Antioxidant Activity and Phenolic Content}

Se, I, and bulk and nano-Si are able to increase the plant antioxidant status, providing resistance to stress factors $[1,13]$. The lack of significant stress factors in the present experiment may be the reason of the low changes in the antioxidant status of chervil subjected to different treatments (Table 3). Total antioxidant activity (AOA) increased significantly only in the case of joint $\mathrm{Se}+\mathrm{I}+\mathrm{Si}$ application, whereas ascorbic acid content reached the highest value under joint I + Si supplementation. The lack of correlation between ascorbic acid content and total antioxidant activity may be explained by the fact that ascorbic acid represents water-soluble antioxidants, while AOA of ethanolic extracts of plants measured in the present investigation reflects the lipid-soluble fraction. It seems obvious that, compared to normal vegetation conditions, stress factors may strengthen the relationship of $\mathrm{Se}$, I and nano-Si, which would guarantee a more intensive beneficial effect of these elements.

\subsection{Mineral Composition}

The mineral composition of plants biofortified with various elements provides a valuable evaluation of the quality characteristics of functional food produced. Despite the importance of this topic, the relationships between Se, I, macro- and micro-elements, as well as toxic elements in plants, have been scantly investigated. In the latter respect, the accumulation of 25 elements in chervil shoots was analyzed and, among the detected differences in macro- and micro-element content, the most important ones related to Se and I. 
Table 3. Total antioxidant activity and phenolic content of chervil leaves under Se, I and Si supplementation.

\begin{tabular}{cccc}
\hline Treatment & $\begin{array}{c}\text { Ascorbic Acid } \\
\text { (mg 100 } \mathbf{~ g}^{-\mathbf{1}} \text { Fresh Weight) }\end{array}$ & $\begin{array}{c}\text { Antioxidant Activity-AOA } \\
\text { (mg GAE } \mathbf{~}^{-1} \text { Dry Weight) }\end{array}$ & $\begin{array}{c}\text { Total Polyphenols-TP } \\
\text { (mg GAE g-1 Dry Weight) }\end{array}$ \\
\hline Control & $30.0 \pm 3.1 \mathrm{~b}$ & $20.2 \pm 2.0 \mathrm{bc}$ & $7.2 \pm 0.71 \mathrm{c}$ \\
$\mathrm{Se}$ & $34.2 \pm 3.4 \mathrm{~b}$ & $24.6 \pm 2.4 \mathrm{~b}$ & $9.8 \pm 0.9 \mathrm{ab}$ \\
$\mathrm{I}$ & $29.8 \pm 3.0 \mathrm{~b}$ & $24.0 \pm 2.3 \mathrm{~b}$ & $9.5 \pm 0.9 \mathrm{ab}$ \\
$\mathrm{Se}+\mathrm{I}$ & $30.4 \pm 3.0 \mathrm{~b}$ & $22.3 \pm 2.2 \mathrm{~b}$ & $10.3 \pm 1.0 \mathrm{a}$ \\
\hline $\mathrm{Si}$ & $31.4 \pm 3.1 \mathrm{~b}$ & $23.7 \pm 2.3 \mathrm{~b}$ & $8.4 \pm 0.8 \mathrm{bc}$ \\
$\mathrm{Si}+\mathrm{Se}$ & $28.5 \pm 2.8 \mathrm{~b}$ & $23.7 \pm 2.3 \mathrm{~b}$ & $9.4 \pm 0.9 \mathrm{ab}$ \\
$\mathrm{Si}+\mathrm{I}$ & $39.0 \pm 3.8 \mathrm{a}$ & $19.1 \pm 1.9 \mathrm{~cd}$ & $8.9 \pm 0.9 \mathrm{ab}$ \\
$\mathrm{Si}+\mathrm{Se}+\mathrm{I}$ & $25.7 \pm 2.6 \mathrm{c}$ & $30.0 \pm 3.0 \mathrm{a}$ & $11.3 \pm 1.0 \mathrm{a}$ \\
\hline
\end{tabular}

Within each column, the values with the same letters do not differ according to Duncan test at $p<0.05$.

\subsubsection{Se, I and Si}

The data presented in Table 4 indicate beneficial interactions between Se and I, considering that supplying each of the two elements increased the accumulation of the other. Contrary, no synergistic effect between Se and I was recorded under joint biofortification of chervil with I and Se. Though Se-I interaction in plants remains poorly investigated, the synergistic effect between Se and I was demonstrated under the joint Se + I biofortification of chickpea [10] and Indian mustard [42]. Nevertheless, other agricultural crops did not reveal such a relationship [1].

Table 4. Levels of Se, I and Si accumulation in chervil shoots under single and joint application of these elements.

\begin{tabular}{cccc}
\hline Treatment & Se & I & Si \\
\hline Control & $0.23 \pm 0.02 \mathrm{f}$ & $0.20 \pm 0.02 \mathrm{e}$ & $20.59 \pm 2.05 \mathrm{ab}$ \\
Se & $3.75 \pm 0.32 \mathrm{ab}$ & $2.50 \pm 0.21 \mathrm{c}$ & $23.81 \pm 2.34 \mathrm{a}$ \\
$\mathrm{I}$ & $0.80 \pm 0.07 \mathrm{c}$ & $16.00 \pm 1.59 \mathrm{~b}$ & $21.97 \pm 2.20 \mathrm{a}$ \\
$\mathrm{Se}+\mathrm{I}$ & $4.36 \pm 0.41 \mathrm{a}$ & $15.00 \pm 1.51 \mathrm{~b}$ & $17.22 \pm 1.71 \mathrm{~b}$ \\
\hline $\mathrm{Si}$ & $0.45 \pm 0.04 \mathrm{e}$ & $1.50 \pm 0.15 \mathrm{~d}$ & $24.10 \pm 2.40 \mathrm{a}$ \\
$\mathrm{Si}+\mathrm{Se}$ & $3.73 \pm 0.35 \mathrm{ab}$ & $1.60 \pm 0.15 \mathrm{~d}$ & $20.14 \pm 2.00 \mathrm{ab}$ \\
$\mathrm{Si}+\mathrm{I}$ & $0.62 \pm 0.06 \mathrm{~d}$ & $34.00 \pm 3.38 \mathrm{a}$ & $19.66 \pm 2.00 \mathrm{ab}$ \\
$\mathrm{Si}+\mathrm{Se}+\mathrm{I}$ & $3.07 \pm 030 \mathrm{~b}$ & $35.00 \pm 3.51 \mathrm{a}$ & $17.16 \pm 1.70 \mathrm{~b}$ \\
\hline
\end{tabular}

$\mathrm{Se}, \mathrm{I}, \mathrm{Si}$ are expressed in $\mathrm{mg} \mathrm{kg}^{-1}$ dry weight. Within each column, values with the same letters do not differ according to Duncan test at $p<0.05$.

In the present investigation, the low concentrations of Si did not elicit significant changes in Si levels in chervil shoots (Table 4). However, nano-Si foliar supply was highly valuable for modulating I but not Se accumulation (Table 4, Figure 3). Indeed, the application of nano-Si increased I accumulation in chervil by 7.5 times, while joint applications of I and I + Se with Si increased I concentration by almost twice compared to a single I application (Figure 3). These results are especially important, as the detected phenomenon is accompanied by plant growth stimulation, contrary to previous works devoted to joint Se + I biofortification, where the increase in I concentration was limited by I toxicity [1]. The comparison of the present results with previous attempts to improve I accumulation upon joint Se + I supplementation, via utilization of salicylic acid [11], vanadium application [9], soil administration of marine algae [41,42] and AMF inoculation [10], suggests high prospects of foliar nano-Si supplementation for production of chervil with elevated levels of Se and I. 




(a)

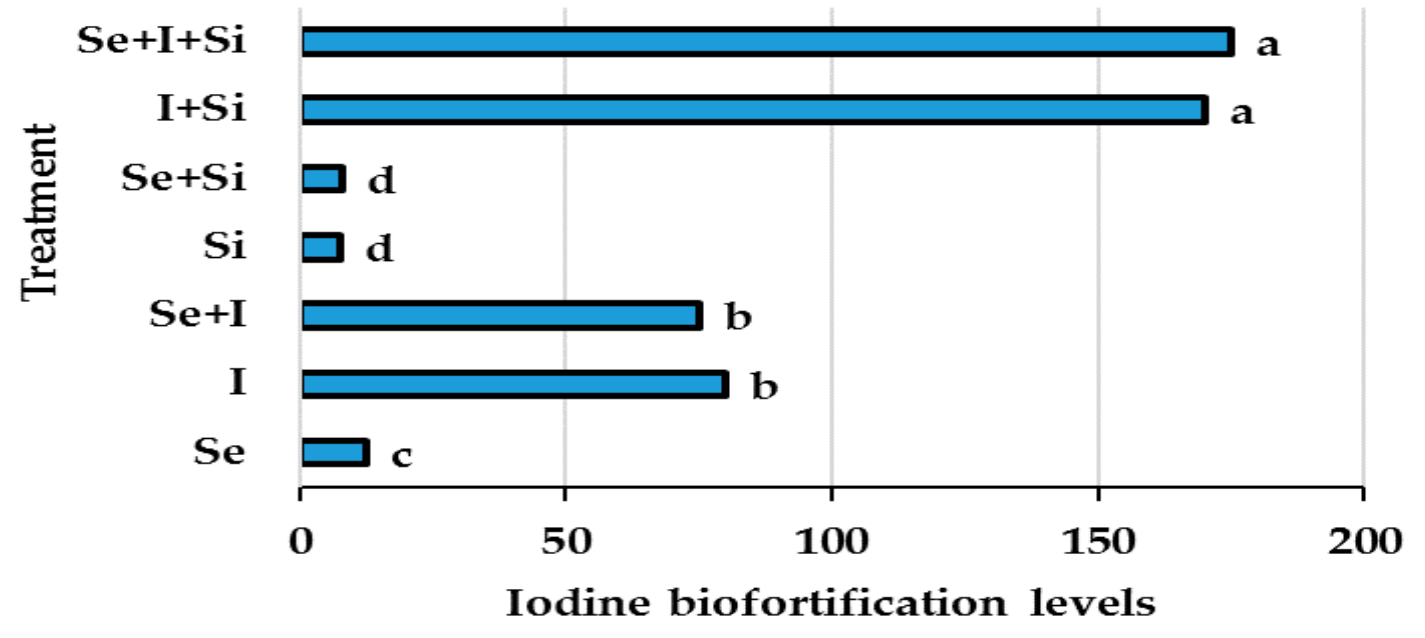

(b)

Figure 3. Biofortification levels (BL) of Se (a) and I (b) in chervil shoots under single and joint application of Se, I and Si (BF is equal to the ratio between element content in the treated and control plants). Values with the same letter do not differ statistically according to Duncan test at $p<0.05$.

As shown in Figure 3a,b, the highest value of Se biofortification was recorded with Se + I application, while the highest I biofortification levels were recorded under foliar nano-Si supply.

Among Se, I and Si relationships in chervil, a small but statistically significant decrease in Si concentration in plants subjected to joint Se + I biofortification was recorded (Table 4); the latter is predominantly connected with the joint application of Se and I, as nano-Si supply did not affect this element concentration due to the low dose. Previous investigations of Indian mustard [42] and chickpea [10] biofortification with I and Se did not reveal any effect of Se and I on Si accumulation [42], which makes it suppose the importance of genetic factors in Se, I and nano-Si interaction. Indeed, these plants differ significantly in the ability to accumulate Se and other macro- and micro-elements, in protein content, resistance to oxidant stress, and have different edible plant parts, such as leaves in chervil and Indian mustard, seeds in chickpea.

Taking into account the non-significant $\mathrm{Si}$ accumulation in chervil plants as a result of low Si dose applied, its beneficial effect on growth, iodine accumulation and nutritional 
value of this crop is surprising. Indeed, most of investigations which reported Si growth promoting activity focused on the application of high $\mathrm{Si}$ concentrations, resulting in significant plant accumulation of this element [43]. In this respect, the close relationship between Si and plant hormonal status may be a possible explanation of this phenomenon. Indeed, silicon supplementation is known to cause significant changes in jasmonic and salicylic acid, auxin and cytokinin biosynthesis [39]. Furthermore, foliar application of low doses of nano- $\mathrm{SiO}_{2}$ on cucumber was shown to greatly affect phytohormones' content: increase in jasmonic and abscisic acid content and decrease in indolyl acetic acid [19]. $\mathrm{Nano}-\mathrm{SiO}_{2}$ significantly decreased $\mathrm{Cd}$ accumulation in cucumber roots, despite the lack of changes in plant $\mathrm{Si}$ levels [19]. Soil application of nano-SiO${ }_{2}$ to cotton at $10 \mathrm{mg} \mathrm{L}^{-1}$ concentration did not cause changes in plant $\mathrm{Si}$ levels but significantly increased indolyl acetic acid production [20]. In the present experiment, nano-Si elicited growth-promoting effect and biochemical changes in chervil also under low $\mathrm{Si}$ dose. Despite the scant data relevant to phytohormone effect on I accumulation [9,11,29], it may be supposed that, at least partially, the Si-I interaction can be achieved through plant hormonal status modification, though additional investigations are needed to confirm this hypothesis.

Considering the Se and I levels in Se/I fortified chervil shoots, the latter may be deemed a new functional food with a significant content of Se and I. Taking into account the adequate Se and I consumption levels (ACL), $50 \mathrm{~g}$ of fresh biofortified chervil shoots can provide up to $25 \%$ of Se ACL $(37 \mu \mathrm{g})$ and $100 \%$ of I ACL, which widens the list of Se/I biofortified vegetables produced up-to-date $[1,9,11]$.

\subsubsection{Macro-Elements}

Different investigations indicate that Se and I biofortification, as well as bulk and nanoSi application, may affect macro- and trace elements accumulation in plants $[10,23,40]$. The data reported in Table 5 reveal that among macro-elements significant changes occurred predominantly for $\mathrm{Na}$, whereas the concentrations of essential elements, such as $\mathrm{P}, \mathrm{K}, \mathrm{Ca}$ and $\mathrm{Mg}$, were not generally affected by Se, I or Si content in chervil shoots.

Table 5. Levels of macro-element accumulation in chervil shoots under single and joint application of Se, I and Si.

\begin{tabular}{|c|c|c|c|c|c|}
\hline Treatment & $\mathrm{Ca}$ & $\mathbf{K}$ & $\mathrm{Mg}$ & $\mathrm{Na}$ & $\mathbf{P}$ \\
\hline Control & $22.45 \pm 2.22 \mathrm{bc}$ & $97.24 \pm 9.71 \mathrm{a}$ & $4.35 \pm 0.43 \mathrm{a}$ & $1.17 \pm 0.11 \mathrm{a}$ & $7.86 \pm 0.78 \mathrm{a}$ \\
\hline Se & $20.09 \pm 20.00 c$ & $108.78 \pm 10.80 \mathrm{a}$ & $3.76 \pm 0.37 \mathrm{a}$ & $0.94 \pm 0.09 \mathrm{a}$ & $8.36 \pm 0.83 a$ \\
\hline $\mathrm{I}$ & $19.03 \pm 19.0 \mathrm{c}$ & $91.07 \pm 9.10 \mathrm{ab}$ & $3.51 \pm 0.35 \mathrm{a}$ & $0.53 \pm 0.05 \mathrm{~d}$ & $6.70 \pm 0.67 \mathrm{a}$ \\
\hline $\mathrm{Se}+\mathrm{I}$ & $25.22 \pm 2.52 \mathrm{ab}$ & $88.22 \pm 8.82 \mathrm{~b}$ & $4.01 \pm 0.40 \mathrm{a}$ & $0.76 \pm 0.08 \mathrm{~b}$ & $6.24 \pm 0.62 \mathrm{a}$ \\
\hline $\mathrm{Si}$ & $22.35 \pm 2.23 b c$ & $83.17 \pm 8.31 \mathrm{ba}$ & $4.11 \pm 0.40 \mathrm{a}$ & $0.72 \pm 0.07 \mathrm{bc}$ & $6.95 \pm 0.69 \mathrm{a}$ \\
\hline $\mathrm{Si}+\mathrm{Se}$ & $22.15 \pm 2.21 b c$ & $88.16 \pm 8,80 \mathrm{ba}$ & $3.66 \pm 0.36 \mathrm{a}$ & $0.44 \pm 0.04 \mathrm{~d}$ & $6.37 \pm 0.63 \mathrm{a}$ \\
\hline $\mathrm{Si}+\mathrm{I}$ & $27.42 \pm 2.74 \mathrm{a}$ & $100.78 \pm 10.11 \mathrm{a}$ & $4.31 \pm 0.43 \mathrm{a}$ & $0.71 \pm 0.07 \mathrm{bc}$ & $7.37 \pm 0.74 \mathrm{a}$ \\
\hline $\mathrm{Si}+\mathrm{Se}+\mathrm{I}$ & $25.01 \pm 2.50 \mathrm{ab}$ & $96.80 \pm 9.66 \mathrm{a}$ & $3.84 \pm 0.38 \mathrm{a}$ & $0.62 \pm 0.06 c$ & $7.21 \pm-0.71 \mathrm{a}$ \\
\hline
\end{tabular}

$\mathrm{Ca}, \mathrm{K}, \mathrm{Mg}$, Na and $\mathrm{P}$ are expressed in $\mathrm{g} \mathrm{kg}^{-1}$ dry weight. Within each column, values with the same letters do not differ according to Duncan test at $p<0.05$.

Previous investigations of I biofortification peculiarities revealed that potassium iodide application reduced $\mathrm{Na}$ accumulation in lettuce seedlings [44]; the latter outcome is consistent with the Na content decrease by almost twice recorded in chervil treated with I, in the present research. Literature reports indicate that both Se and I can alleviate salt stress in plants $[45,46]$.

A high $\mathrm{K}^{+} / \mathrm{Na}^{+}$ratio in the cytosol guarantees plant resistance to salt stress [47]. The data reported in Table 5 indicate that the highest $\mathrm{K} / \mathrm{Na}$ ratios relate to the joint application of Si with Se and/or I (142-200 compared to 83 in control plants), whereas a much smaller effect was recorded under Se, Se + I or Si supplementation (K/Na ratio equal to 116). Indeed, $\mathrm{Na}^{+}$content decreased by 2.66 times in the case of $\mathrm{Se}+\mathrm{Si}$ application, by 1.6 times under I + Si and Si supplementation and by 1.9 times upon joint $\mathrm{Se}+\mathrm{I}+\mathrm{Si}$ application. This phenomenon demonstrates additional benefits in Se and I joint utilization under foliar 
nano-Si supply. Up to date, alleviation of plant salt stress using nano-Si was reported only in the case of soil $\mathrm{Si}$ supplementation, which reduced $\mathrm{NaCl}$ accumulation, thus promoting root growth $[48,49]$ and decreasing root-to-shoot translocation of $\mathrm{Na}^{+}$[50]. Notably, studies of Si interaction with other macro-elements were carried out only on soil application of bulk $\mathrm{Si}$ [23], while no information is available on the foliar effect of nano-Si.

\subsubsection{Micro-Elements}

To date, there are extremely scant data regarding the interaction of I with other elements [51], while Se supplementation effect on plant mineral composition greatly varied depending on the species investigated, methods and doses of Se supplementation [52]. The biofortification of chervil with I and Se resulted in a decrease in Fe, Mn, Zn, Mo and Co, while joint application of Se and I did not change the concentration of these elements. The ability of I to reduce the concentration of Fe, Mn and $\mathrm{Zn}$ was previously demonstrated in lettuce seedlings [44]. Controversial data were obtained with other agricultural crops: Se/I biofortification of chickpea resulted in no changes of the element content [10]; no effect on micro-elements content was recorded also in shallot [53], onion and garlic [54], fortified with Se, while an increase in the concentration of $\mathrm{Fe}, \mathrm{Mn}$ and $\mathrm{Zn}$ was recorded in Indian mustard under foliar Se and I biofortification [42].

The present results on chervil biofortification with Se and I indicated for the first time the importance of foliar nano-Si application in restoring Fe and Mn levels in plants (Table 6). The known relationship between Fe and Mn was confirmed by the Mn level changes, where the highest content was $93.7 \mathrm{mg} \mathrm{kg}^{-1} \mathrm{~d} . \mathrm{w}$. in the case of nano-Si application, compared to 1.5-times lower values in control plants. The coefficient of correlation between Fe and Mn was equal to 0.918 ( $p<0.01$ ) (Figure 4). Up-to-date only one work devoted to foliar application of nano-Si on rice seedlings reported changes in micro-element content as affected by nano-Si and Cd application [55], where an increase in $\mathrm{Mg}$, Fe and $\mathrm{Zn}$ content was detected [55].

Table 6. Levels of micro-element accumulation in chervil shoots under single and joint application of Se, I and Si.

\begin{tabular}{|c|c|c|c|c|c|c|c|c|}
\hline Treatment & B & Co & $\mathrm{Cu}$ & $\mathrm{Fe}$ & $\mathbf{L i}$ & Mn & Mo & $\mathrm{Zn}$ \\
\hline Control & $32.18 \pm 3.21 \mathrm{ab}$ & $0.42 \pm 0.04 b c$ & $21.33 \pm 2.11 \mathrm{a}$ & $1323 \pm 132 b$ & $0.93 \pm 0.09 \mathrm{ab}$ & $61.82 \pm 6.18 \mathrm{~b}$ & $1.85 \pm 0.18 \mathrm{a}$ & $244 \pm 24 a$ \\
\hline $\mathrm{Se}$ & $33.77 \pm 3.37 \mathrm{ab}$ & $0.33 \pm 0.03 \mathrm{~d}$ & $18.85 \pm 1.88 \mathrm{ab}$ & $776 \pm 77 \mathrm{~d}$ & $0.76 \pm 0.07 \mathrm{bc}$ & $43.61 \pm 4.36 c$ & $1.43 \pm 0.14 \mathrm{~b}$ & $143 \pm 14 b c$ \\
\hline I & $27.55 \pm 2.75 b$ & $0.33 \pm 0.03 \mathrm{~d}$ & $15.57 \pm 1.55 \mathrm{c}$ & $753 \pm 75 d$ & $0.65 \pm 0.06 \mathrm{c}$ & $42.94 \pm 4.29 \mathrm{c}$ & $1.46 \pm 0.15 b$ & $121 \pm 12 \mathrm{c}$ \\
\hline $\mathrm{Se}+\mathrm{I}$ & $33.29 \pm 3.33 \mathrm{ab}$ & $0.52 \pm 0.05 \mathrm{~b}$ & $16.78 \pm 1.67 \mathrm{c}$ & $1486 \pm 148 b$ & $1.06 \pm 0.11 \mathrm{a}$ & $66.54 \pm 6.65 b$ & $2.06 \pm 0.20 \mathrm{a}$ & $202 \pm 20 a$ \\
\hline $\mathrm{Si}$ & $31.34 \pm 3.13 \mathrm{ab}$ & $0.77 \pm 0.07 \mathrm{a}$ & $16.76 \pm 1.67 c$ & $1880 \pm 188 \mathrm{a}$ & $1.01 \pm 0.10 \mathrm{a}$ & $93.71 \pm 9.37 \mathrm{a}$ & $1.69 \pm 0.17 \mathrm{a}$ & $166 \pm 16 b$ \\
\hline $\mathrm{Si}+\mathrm{Se}$ & $35.25 \pm 3.52 \mathrm{a}$ & $0.39 \pm 0.04 \mathrm{~cd}$ & $14.16 \pm 1.41 \mathrm{c}$ & $1237 \pm 124 \mathrm{bc}$ & $0.87 \pm 0.09 \mathrm{~b}$ & $46.10 \pm 4.60 \mathrm{c}$ & $1.80 \pm 0.18 \mathrm{a}$ & $118 \pm 12 c$ \\
\hline $\mathrm{Si}+\mathrm{I}$ & $34.07 \pm 3.40 \mathrm{a}$ & $0.49 \pm 0.05 b$ & $17.47 \pm 1.75 \mathrm{a}$ & $1161 \pm 116 c$ & $0.92 \pm 0.09 \mathrm{ab}$ & $62.30 \pm 6.22 b$ & $1.90 \pm 0.19 \mathrm{a}$ & $145 \pm 15 b c$ \\
\hline $\mathrm{Si}+\mathrm{Se}+\mathrm{I}$ & $36.42 \pm 3.62 \mathrm{a}$ & $0.51 \pm 0.05 \mathrm{~b}$ & $17.14 \pm 1.71 \mathrm{bc}$ & $1306 \pm 130 \mathrm{bc}$ & $1.09 \pm 0.11 \mathrm{a}$ & $63.81 \pm 6.38 \mathrm{~b}$ & $1.95 \pm 0.19 \mathrm{a}$ & $161 \pm 16 \mathrm{~b}$ \\
\hline
\end{tabular}

$\mathrm{B}, \mathrm{Co}, \mathrm{Cu}, \mathrm{Fe}, \mathrm{Li}, \mathrm{Mn}, \mathrm{Mo}$ and $\mathrm{Zn}$ are expressed in $\mathrm{mg} \mathrm{kg}^{-1}$ dry weight. Within each column, values with the same letters do not differ according to Duncan test at $p<0.05$.

\subsubsection{As, $\mathrm{Al}, \mathrm{Cd}, \mathrm{Cr}, \mathrm{Ni}, \mathrm{Pb}, \mathrm{Sr}$ and $\mathrm{V}$}

It is well known that $S e$ is an important antagonist of toxic metals and metalloids [52,56]. Indeed, Se biofortification resulted in a significant decrease in $\mathrm{As}, \mathrm{Cr}, \mathrm{Pb}, \mathrm{Sr}$ and $\mathrm{V}$ content in chervil shoots, even without toxic element uptake (Table 7). Up to date, there are extremely scant data relevant to the interaction of I with other elements [51]. In the present study, I treatment resulted in a decrease in $\mathrm{Cr}$ and $\mathrm{Pb}$ in chervil shoots, while no changes were observed in plants subjected to joint supplementation with I and Se (Table 7). 


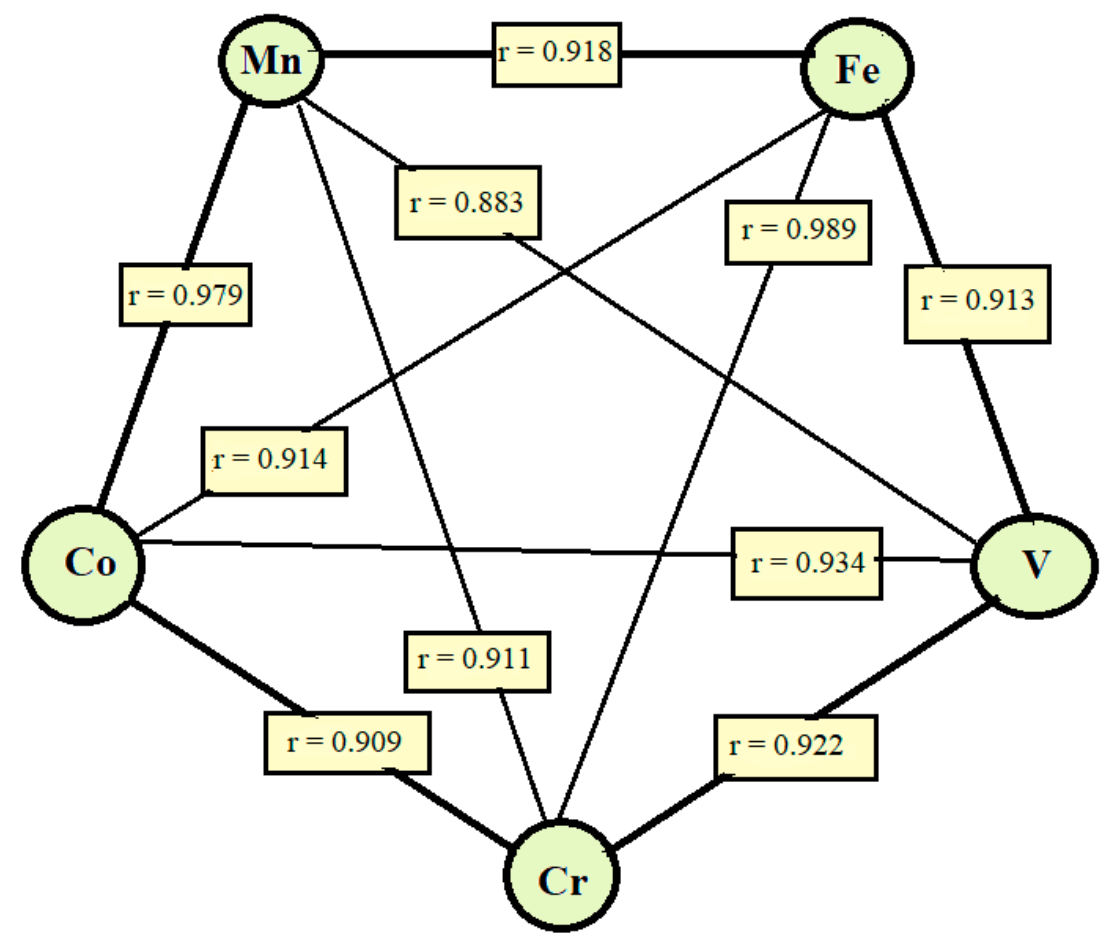

Figure 4. The most intensive relationships between the elements investigated in chervil shoots $(p<0.001)$.

Table 7. Levels of As, $\mathrm{Al}, \mathrm{Cd}, \mathrm{Cr}, \mathrm{Ni}, \mathrm{Pb}, \mathrm{Sr}$ and $\mathrm{V}$ accumulation in chervil shoots under single and joint application of Se, I and $\mathrm{Si}$.

\begin{tabular}{|c|c|c|c|c|c|c|c|c|}
\hline Treatment & Al & As & $\mathrm{Cd}$ & $\mathrm{Cr}$ & $\mathrm{Ni}$ & $\mathbf{P b}$ & Sr & V \\
\hline Control & $364 \pm 36$ de & $0.28 \pm 0.03 \mathrm{~d}$ & $1.09 \pm 0.11 \mathrm{~b}$ & $13.39 \pm 1.3 \mathrm{bc}$ & $3.51 \pm 0.35 \mathrm{ab}$ & $3.59 \pm 0.36 \mathrm{a}$ & $105.0 \pm 10.0 \mathrm{a}$ & $1.33 \pm 0.13 \mathrm{~cd}$ \\
\hline Se & $350 \pm 35 \mathrm{e}$ & $0.23 \pm 0.02 \mathrm{e}$ & $1.15 \pm 0.11 \mathrm{ab}$ & $9.14 \pm 0.91 \mathrm{~d}$ & $3.33 \pm 0.33 b c$ & $2.55 \pm 0.25 \mathrm{~b}$ & $81.5 \pm 8.1 \mathrm{~b}$ & $1.04 \pm 0.10 \mathrm{e}$ \\
\hline I & $305 \pm 30 \mathrm{e}$ & $0.27 \pm 0.03 \mathrm{de}$ & $1.06 \pm 0.10 \mathrm{~b}$ & $8.29 \pm 0.82 \mathrm{~d}$ & $3.02 \pm 0.30 \mathrm{c}$ & $2.67 \pm 0.26 \mathrm{~b}$ & $87.5 \pm 8.7 \mathrm{ab}$ & $1.12 \pm 0.11 \mathrm{de}$ \\
\hline $\mathrm{Se}+\mathrm{I}$ & $568 \pm \mathrm{ab}$ & $0.41 \pm 0.04 \mathrm{~b}$ & $1.04 \pm 0.10 \mathrm{~b}$ & $14.75 \pm 1.43 \mathrm{ab}$ & $3.68 \pm 0.36 \mathrm{ab}$ & $3.53 \pm 0.25 \mathrm{a}$ & $112.0 \pm 11.1 \mathrm{a}$ & $1.79 \pm 0.18 b$ \\
\hline $\mathrm{Si}$ & $513 \pm 51 b c$ & $0.71 \pm 0.07 \mathrm{a}$ & $1.17 \pm 0.11 \mathrm{ab}$ & $17.70 \pm 1.76 \mathrm{a}$ & $3.43 \pm 0.34 \mathrm{ab}$ & $3.55 \pm 0.25 \mathrm{a}$ & $109.0 \pm 10.7 \mathrm{a}$ & $2.32 \pm 0.23 \mathrm{a}$ \\
\hline $\mathrm{Si}+\mathrm{Se}$ & $504 \pm 50 \mathrm{bc}$ & $0.32 \pm 0.03 \mathrm{~cd}$ & $1.03 \pm 0.10 b$ & $12.81 \pm 1.26 \mathrm{c}$ & $3.20 \pm 0.32 \mathrm{cb}$ & $2.41 \pm 0.24 b$ & $82.8 \pm 8.2 \mathrm{~b}$ & $1.52 \pm 0.15 c$ \\
\hline $\mathrm{Si}+\mathrm{I}$ & $431 \pm 43 \mathrm{~cd}$ & $0.32 \pm 0.03 \mathrm{~cd}$ & $1.30 \pm 0.13 \mathrm{a}$ & $12.91 \pm 1.29 c$ & $4.26 \pm 0.42 \mathrm{a}$ & $2.93 \pm 0.29 b$ & $94.1 \pm 9.4 \mathrm{ab}$ & $1.49 \pm 0.15 c$ \\
\hline $\mathrm{Si}+\mathrm{Se}+\mathrm{I}$ & $660 \pm 66 a$ & $0.34 \pm 0.03 \mathrm{bc}$ & $1.35 \pm 0.13 \mathrm{a}$ & $14.01 \pm 1.40 \mathrm{bc}$ & $3.93 \pm 0.39 \mathrm{a}$ & $3.78 \pm 0.38 \mathrm{a}$ & $99.4 \pm 9.9 \mathrm{ab}$ & $1.95 \pm 0.19 \mathrm{ab}$ \\
\hline
\end{tabular}

$\mathrm{Al}, \mathrm{As}, \mathrm{Cd}, \mathrm{Cr}, \mathrm{Ni}, \mathrm{Pb}, \mathrm{Sr}, \mathrm{V}$ are expressed in $\mathrm{mg} \mathrm{kg}^{-1}$ dry weight. Within each column, values with the same letters do not differ according to Duncan test at $p<0.05$.

In agriculture, Si nanoparticles are highly valuable in plant protection against metal toxicity [57], though the protection effect closely relates to soil application. The foliar nano-Si application showed the most interesting beneficial effects on $\mathrm{V}$ levels (Table 7), as the latter is known to participate in $\mathrm{I}, \mathrm{Cr}$ and $\mathrm{Al}$ accumulation. Nano-Si application to chervil resulted in restoration of $\mathrm{Cr}$ content in plants, which decreased due to Se and I biofortification, a significant increase in I accumulation (Table 4) and pronounced $\mathrm{Al}$ content rise (Table 7). The phenomenon of $\mathrm{V}, \mathrm{Cr}$ and $\mathrm{Al}$ increase does not cause any ecological risks due to rather low levels of these elements and indicates the possibility of nano-Si participation in the element distribution. Notably, foliar nano-Si effect on $\mathrm{Al}$ accumulation in chervil plants contrasts with the $\mathrm{Al}$ accumulation decrease under soil Si application [43].

\subsubsection{Correlations}

The coefficients of correlations between the analyzed mineral elements in chervil shoots provided a complex frame of interactions (Supplement Table S1), the most intensive ones being between $\mathrm{Mn}, \mathrm{Fe}, \mathrm{V}, \mathrm{Cr}$ and $\mathrm{Co}$ (Figure 4), while no significant correlations were detected for $\mathrm{B}$ and $\mathrm{Mg}$. The lack of correlations between the mentioned elements 
and the foliar-supplied ones (Se, I, Si) suggests the indirect effect of Se, I and Si, on plant elemental status.

\section{Materials and Methods}

\subsection{Growing Conditions and Experimental Protocol}

The experiment was conducted in 2020 and 2021 at the Federal Scientific Vegetable Center (Moscow region; $55^{\circ} 39^{\prime} 23^{\prime \prime} \mathrm{N}, 37^{\circ} 12^{\prime} 43^{\prime \prime} \mathrm{E}$ ), in plastic pots using chervil seeds of the genotype 21-20 sown on 6 June. The values of mean temperature and relative humidity, and total photosynthetically active radiation (PAR) during the vegetation period were: in 2020, $21.0{ }^{\circ} \mathrm{C}, 73.0 \%$ and $293 \mathrm{MJ} \mathrm{m}^{-2}$ in June, and $23.8^{\circ} \mathrm{C}, 74.9 \%$ and $244 \mathrm{MJ} \mathrm{m}^{-2}$ in July; in $2021,17.2^{\circ} \mathrm{C}, 69 \%$ and $285 \mathrm{MJ} \mathrm{m}^{-2}$ in June, and $20.1^{\circ} \mathrm{C}, 72.0 \%$ and $232 \mathrm{MJ} \mathrm{m}^{-2}$ in July. The photoperiod duration (day length) was 17.20-17.33 in June and 17.26-16.0 in July.

Each pot (10 L volume, $25 \mathrm{~cm}$ diameter, $20 \mathrm{~cm}$ height) contained a field clay-loam soil, with the following characteristics: $\mathrm{pH} 6.8,2.1 \%$ organic matter; $1.32 \mathrm{mg}$-eq $100 \mathrm{~g}^{-1}$ hydrolytic acidity; $18.5 \mathrm{mg} \mathrm{kg}^{-1}$ mineral nitrogen; $21.3 \mathrm{mg} \mathrm{kg}^{-1}$ ammonium nitrogen; $402 \mathrm{mg} \mathrm{kg}^{-1}$ mobile phosphorous; $198 \mathrm{mg} \mathrm{kg}^{-1}$ exchangeable potassium; sum of absorbed bases as much as $93.6 \%$; cation exchange capacity as much as $15 \mathrm{mg}$-eq $100 \mathrm{~g}^{-1}$ soil; soil moisture field capacity as much as $25.2 \%$.

All the pots were placed outdoors under a plastic shelter protecting from rainwater. Each pot had a tray for collecting leaching water, which was recycled during the next irrigation. The experimental protocol included eight treatments: (1) control (without any supplementation); (2) foliar supplementation of $\mathrm{Na}_{2} \mathrm{SeO}_{4}$ solution $\left(10 \mu \mathrm{g} \mathrm{L}^{-1}\right)$; (3) foliar supplementation of KI (150 mg L $\left.\mathrm{mg}^{-1}\right)$; (4) foliar supplementation of nano-Si $\left(14 \mathrm{mg} \mathrm{L}^{-1}\right)$; (5) foliar supplementation of $\mathrm{Na}_{2} \mathrm{SeO}_{4}$ and $\mathrm{KI}$ with the above-indicated concentrations; (6) foliar supplementation of $\mathrm{Na}_{2} \mathrm{SeO}_{4}$ + nano-Si with the above-indicated concentrations; (7) supplementation of KI + nano-Si with the above-indicated concentrations; and (8) foliar supplementation of $\mathrm{Na}_{2} \mathrm{SeO}_{4}+\mathrm{KI}+$ nano-Si with the above-indicated concentrations. The volume of solutions per pot was $50 \mathrm{~mL}$. A randomized complete block design was used for the treatment distribution in the field, with three replicates, and each treatment consisted of four pots. On 6 June, 30 chervil seeds were sown in each pot, with a density of 16 pots per $\mathrm{m}^{2}$. The plants were watered three times a week to prevent any water stress during the whole growing period. On 5 August, all plants were harvested, separated into shoots and roots, washed with tap water, rinsed several times with distilled water, dried with filter paper and weighed to assess the biomass, dried up to constant weight at $70{ }^{\circ} \mathrm{C}$ and homogenized.

\subsection{Colloidal Solution of Silicon Nanoparticles}

\subsubsection{Laser Ablation in Liquid (LAL)}

Si nanoparticles in the form of a colloidal solution were obtained by pulsed laser ablation in a liquid (LAL). The irradiation was achieved by using a pulsed nanosecond $\mathrm{Nd}$ :YAG laser with a wavelength $\lambda=1064 \mathrm{~nm}$. The laser pulse length was $12 \mathrm{~ns}$ and pulses frequency-1 Hz. Rated energy in the pulse was $2.5 \mathrm{~J}$. As a target, special-purity grade single-crystalline silicon was sprayed. The target was immersed in a static glass cell with $250 \mathrm{~mL}$ of deionized water. The laser beam was focused on target inside the cell by lens. The target was irradiated for $30 \mathrm{~min}$ without stirring.

\subsubsection{Inductively Coupled Plasma Atomic Emission Spectrometry (ICP-AES)}

The silicon concentrations in the obtained colloidal solutions were measured by inductively coupled plasma atomic emission spectrometry (ICP-AES) with an ULTIMA 2 (Horiba Jobin Yvon, France) spectrometer. Monochromator-holographic grating 2400 lines mm $^{-1}$, focal length $1 \mathrm{~m}$. Sample preparation consisted of sequential dilution of the initial colloidal solutions with high purity grade water by a factor of 5 or more until the required concentration was obtained. Diluted solutions were sprayed into the plasma torch of the spectrometer by Meinhard atomizer. Colloidal solutions of silicon in water do not require 
preliminary dissolution of samples. For the determination of silicon, the most sensitive analytical line at $251.611 \mathrm{~nm}$ was chosen. The aqueous base of solutions, as well as the presence of one element in the solution, makes it possible to determine the concentration of silicon without the influence of other elements.

\subsubsection{Dynamic Light Scattering (DLS) and Z-Potential}

Sizes of the dispersed phase particles were measured by dynamic light scattering (DLS) method using Photocor Compact Z (Photocor, USA) laser analyzer with a wavelength $\lambda=589 \mathrm{~nm}$ and laser rated-power output of $32 \mathrm{~mW}$. To estimate the surface charge of particles of colloidal solution, the magnitude of the electrokinetic potential $(\zeta, \mathrm{mV})$ was determined via electrophoresis using the same instrument. To this end, $2 \mathrm{~mL}$ of colloidal solution was added in a quartz cell at $25^{\circ} \mathrm{C}$ for the analysis.

The concentration of silicon in the colloidal solution was equal to $14 \mathrm{mg} \mathrm{L}^{-1}$. To assess the aging of the colloidal solution, two types of solutions were analyzed. Figure 5 shows the particle size distribution in a freshly prepared colloidal solution.

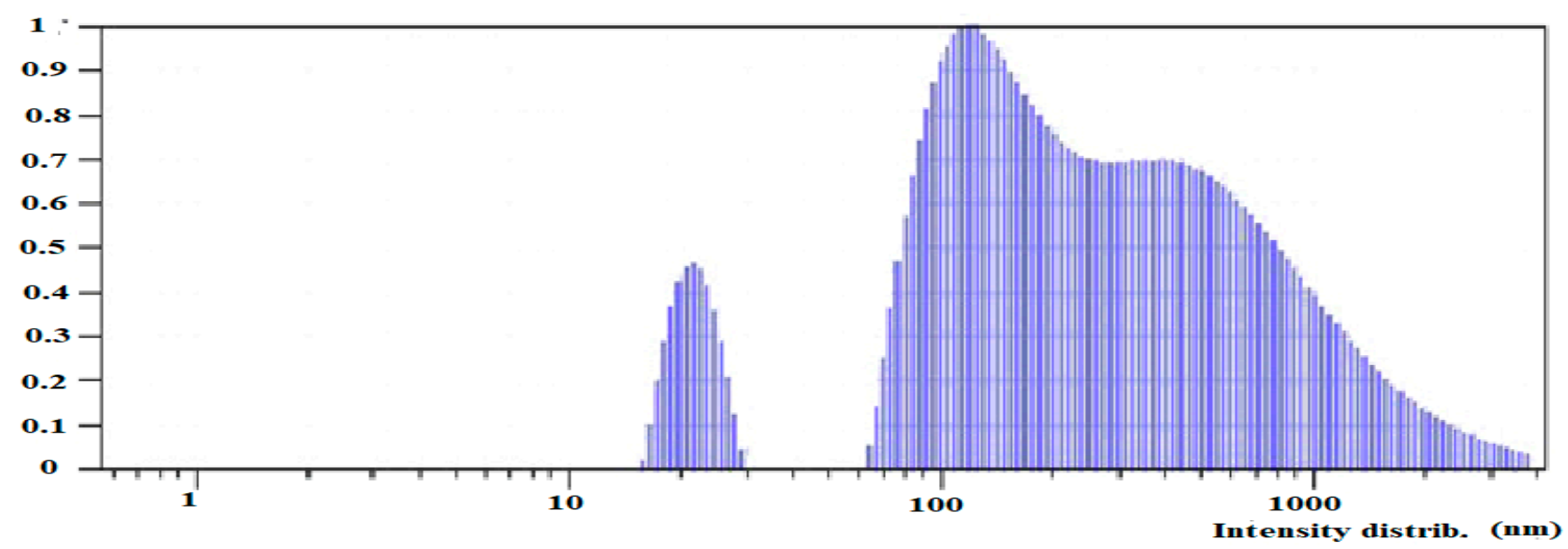

Figure 5. Silicon particle size distribution of freshly prepared colloidal solution.

The sedimentation process in the freshly prepared solution results in a wide particle size distribution. The first relatively narrow peak shows mean particle size of about $22 \mathrm{~nm}$. The second range is from $80 \mathrm{~nm}$ to $3 \mu \mathrm{m}$. The second type of solution was settled for 1 month (Figure 6).

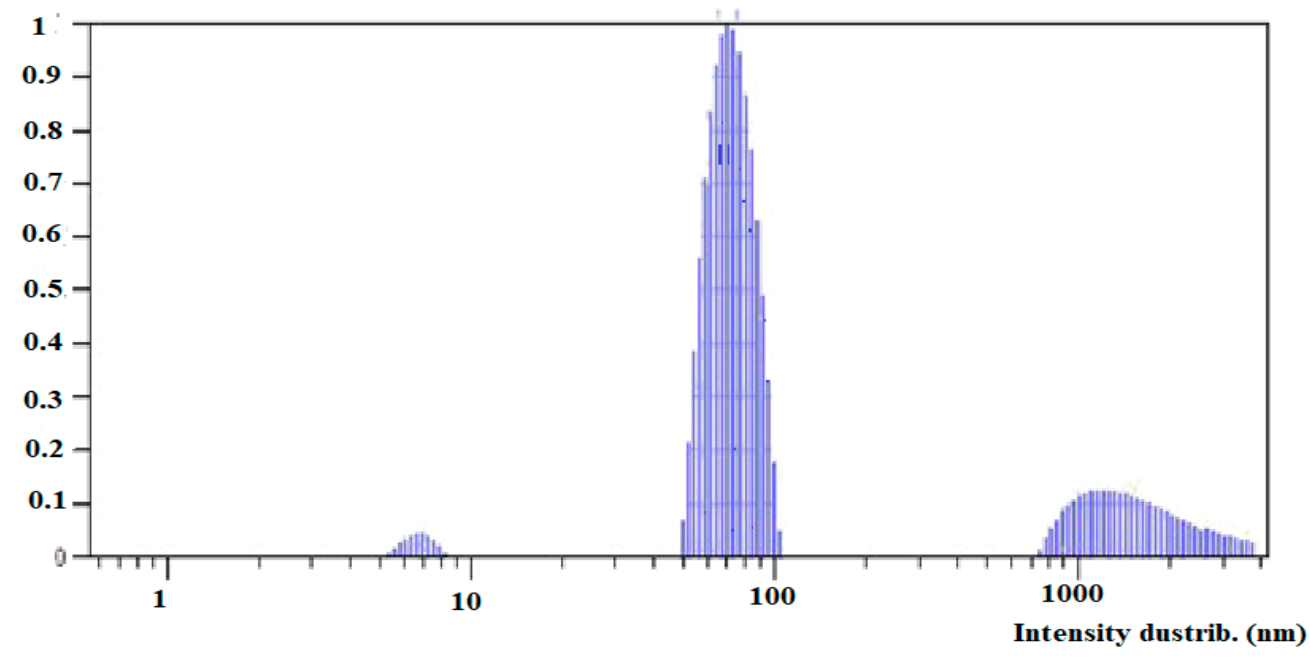

Figure 6. Silicon particle size distribution of aged colloidal solution. 
Figure 6 shows 3 peaks with mean particle size of $7 \mathrm{~nm}, 72 \mathrm{~nm}$ and $1.6 \mu \mathrm{m}$. The last peak was formed after vigorous stirring of the solution. The $\zeta$-potential of the aged and new solution did not differ significantly and was estimated at about $-33.5 \mathrm{mV}$.

\subsection{Biochemical Analyses and Elemental Composition of Plants}

\subsubsection{Dry Matter}

The dry matter was assessed gravimetrically by drying the samples in an oven at $70{ }^{\circ} \mathrm{C}$ until constant weight.

\subsubsection{Photosynthetic Pigments}

Half a gram of fresh leaf sample was homogenized in a porcelain mortar with $10 \mathrm{~mL}$ of $96 \%$ ethanol. The homogenized sample mixture was quantitatively transferred to a volumetric flask, bringing the volume to $25 \mathrm{~mL}$ and the mixture was filtered through filter paper. The resulting solution was analyzed for Chlorophyll-a, Chlorophyll-b and carotene determination through a spectrophotometer (Unico 2804 UV, USA). Calculation of chlorophyll and carotene concentrations was achieved using appropriate equations [58]:

$$
\begin{gathered}
\text { Ch-a }=13.36 \mathrm{~A}_{664}-5.19 \mathrm{~A}_{649} ; \\
\mathrm{Ch}-\mathrm{b}=27.43 \mathrm{~A}_{649}-8.12 \mathrm{~A}_{664} ; \\
\mathrm{C} \mathrm{c}=\left(1000 \mathrm{~A}_{470}-2.13 \mathrm{Ch}-\mathrm{a}-87.63 \mathrm{Ch}-\mathrm{b}\right) / 209 ;
\end{gathered}
$$

where $\mathrm{A}=$ Absorbance, $\mathrm{Ch}-\mathrm{a}=$ Chlorophyll $\mathrm{a}, \mathrm{Ch}-\mathrm{b}=$ Chlorophyll $\mathrm{b}$ and $\mathrm{C} \mathrm{c}=$ Carotene .

\subsubsection{Ascorbic Acid}

The ascorbic acid content was determined by visual titration of plant extracts in $6 \%$ trichloracetic acid with Tillman's reagent [59]. Three grams of fresh chervil leaves were homogenized in a porcelain mortar with $5 \mathrm{~mL}$ of $6 \%$ trichloracetic acid and quantitatively transferred to a measuring cylinder. The volume was brought to $60 \mathrm{~mL}$ using trichloracetic acid, and the mixture was filtered through filter paper 15 min later. The concentration of ascorbic acid was determined from the amount of Tillman's reagent that went into titration of the sample.

\subsubsection{Preparation of Ethanolic Extracts}

Half a gram of dry homogenized chervil shoots was extracted with $20 \mathrm{~mL}$ of $70 \%$ ethanol at $80^{\circ} \mathrm{C}$ over $1 \mathrm{~h}$. The mixture was cooled and quantitatively transferred to a volumetric flask, and the volume was adjusted to $25 \mathrm{~mL}$. The mixture was filtered through filter paper and used further for the determination of polyphenols (TP) and total antioxidant activity (AOA) [60].

\subsubsection{Total Polyphenols (TP)}

Polyphenols were determined spectrophotometrically based on the Folin-Ciocalteu colorimetric method according to Golubkina et al. [59].

The concentration of polyphenols was calculated according to the absorption of the reaction mixture at $730 \mathrm{~nm}$ using $0.02 \%$ gallic acid as an external standard. The results were expressed in $\mathrm{mg}$ of gallic acid equivalent per $\mathrm{g}$ of dry weight ( $\mathrm{mg} \mathrm{GAE} \mathrm{g}^{-1}$ d.w.)

\subsubsection{Antioxidant Activity (AOA)}

The antioxidant activity was measured via titration of $0.01 \mathrm{~N} \mathrm{KMnO} 4$ solution with ethanolic extracts of dry samples [59].

\subsubsection{Nitrates}

Nitrates were assessed using ion-selective electrodes of an ionomer Expert-001 (Econix Inc., Moscow, Russia) [27]. Five grams of fresh chervil shoots were homogenized with $50 \mathrm{~mL}$ of distilled water. Forty-five $\mathrm{mL}$ of the resulting extract were mixed with $5 \mathrm{~mL}$ of 
$0.5 \mathrm{M}$ potassium sulfate background solution (necessary for regulating the ionic strength) and analyzed through an ionomer for nitrate determination.

\subsubsection{Element Composition}

$\mathrm{Al}, \mathrm{As}, \mathrm{B}, \mathrm{Ca}, \mathrm{Cd}, \mathrm{Co}, \mathrm{Cr}, \mathrm{Cu}, \mathrm{Fe}, \mathrm{Hg}, \mathrm{K}, \mathrm{Li}, \mathrm{Mg}, \mathrm{Mn}, \mathrm{Na}, \mathrm{Ni}, \mathrm{P}, \mathrm{Pb}, \mathrm{Si}, \mathrm{Sn}, \mathrm{Sr}, \mathrm{V}$, and $\mathrm{Zn}$ contents in dried homogenized samples were assessed using ICP-MS on quadruple mass-spectrometer Nexion 300D (Perkin Elmer Inc., Shelton, CT, USA), equipped with the seven-port FAST valve and ESI SC DX4 autosampler (Elemental Scientific Inc., Omaha, NE, USA) at the Biotic Medicine Center (Moscow, Russia). Rhodium 103 Rh was used as an internal standard to eliminate instability during measurements. Quantitation was performed using external standard (Merck IV, multi-element standard solution); PerkinElmer standard solutions for $\mathrm{P}, \mathrm{Si}$, and $\mathrm{V}$, and all the standard curves were obtained at five different concentrations. For quality control purposes, internal controls and reference materials were tested together with the samples daily. Microwave digestion of samples was carried out with sub-boiled $\mathrm{HNO}_{3}$ diluted 1:150 with distilled deionized water (Fluka No. 02, 650 Sigma-Aldrich, Co., Saint Louis, MO, USA) in the Berghof SW-4 DAP-40 microwave system (Berghof Products + Instruments Gmb H, 72, 800 Eningen, Germany). The instrument conditions and acquisition parameters were: plasma power and argon flow, 1500 and $18 \mathrm{~L} \mathrm{~min}^{-1}$, respectively; aux argon flow, $1.6 \mathrm{~L} \mathrm{~min}{ }^{-1}$; nebulizer argon flow, $0.98 \mathrm{~L}$ $\mathrm{min}^{-1}$; sample introduction system, ESI ST PFA concentric nebulizer and ESI PFA cyclonic spray chamber (Elemental Scientific Inc., Omaha, NE, USA); sampler and slimmer cone material, platinum; injector, ESI Quartz $2.0 \mathrm{~mm}$ I.D.; sample flow, $637 \mathrm{~L} \mathrm{~min}^{-1}$; internal standard flow, $84 \mathrm{~L} \mathrm{~min}^{-1}$; dwell time and acquisition mode, 10-100 $\mathrm{ms}$ and peak hopping for all analytes; sweeps per reading, 1; reading per replicate, 10; replicate number, 3; DRC mode, $0.55 \mathrm{~mL} \mathrm{~min}^{-1}$ ammonia (294993-Aldrich Sigma-Aldrich, Co., St. Louis, MO 63103, USA) for $\mathrm{Ca}, \mathrm{K}, \mathrm{Na}, \mathrm{Fe}, \mathrm{Cr}, \mathrm{V}$, optimized individually for $\mathrm{RPa}$ and $\mathrm{RPq}$; STD mode, for the rest of analytes at $\mathrm{RPa}=0$ and $\mathrm{RPq}=0.25$ [61].

Trace levels of $\mathrm{Hg}$ and $\mathrm{Sn}$ in samples were not taken into account and, accordingly, they were not included in the tables.

\subsubsection{Determination of Iodine}

Determination of iodine was carried out according to [60], using the Voltamperometric Analyzer TA-4 (Tomanalyte, Tomsk, Russia) equipped with built-in UV lamp and threeelectrode electrochemical cell: auxiliary and reference electrodes (silver chlorides in $1 \mathrm{M}$ $\mathrm{KCl}$ ), and working electrode, i.e., a modified silver electrode. Then, $2 \mathrm{~mL}$ of $10 \% \mathrm{KOH}$ solution was added to $0.1 \mathrm{~g}$ of dried homogenized samples, which were ashed at $40-550{ }^{\circ} \mathrm{C}$. The mixtures were cooled down, $1 \mathrm{~mL}$ of $10 \%$ zinc sulfate solution was added, and ashing was repeated in the same mode. The resulting white probes were dissolved in $10 \mathrm{~mL}$ of distilled water, and iodine concentration was determined using concentrated formic acid as a background electrolyte and standard potassium iodide solutions of $0.1 \mathrm{mg} \cdot \mathrm{L}^{-1}, 1 \mathrm{mg} \cdot \mathrm{L}^{-1}$, and $10 \mathrm{mg} \cdot \mathrm{L}^{-1}$.

\subsubsection{Determination of Selenium}

Selenium was analyzed using the fluorimetric method previously described for tissues and biological fluids [62]. Dried homogenized samples were digested via heating with a mixture of nitric and chloral acids, subsequent reduction of selenate $\left(\mathrm{Se}^{+6}\right)$ to selenite $\left(\mathrm{Se}^{+4}\right)$ with a solution of $6 \mathrm{~N} \mathrm{HCl}$, and formation of a complex between $\mathrm{Se}^{+4}$ and 2,3diaminonaphtalene. Calculation of the Se concentration was achieved by recording the piazoselenol fluorescence value in hexane at $519 \mathrm{~nm} \lambda$ emission and $376 \mathrm{~nm} \lambda$ excitation. Each determination was performed in triplicate. The precision of the results was verified using a reference standard of Se fortified chervil stem powder in each determination with a Se concentration of $1865 \mu \mathrm{g} \mathrm{Kg}^{-1}$ (Federal Scientific Vegetable Center). 


\subsubsection{Biofortification Values}

The evaluation of the efficiency of Se and I biofortification of chervil shoots was achieved using the so-called "biofortification level" (BL), which was calculated according to the equation:

$$
\mathrm{BL}=\mathrm{C}_{1} / \mathrm{C}_{2} \text {, }
$$

where $C_{1}$ is the concentration of Se/I in leaves of biofortified plants and $C_{2}$ the concentration of Se/I in leaves of control plants.

\subsection{Statistical Analysis}

Data were processed by analysis of variance, and mean separations were performed through Duncan's multiple range test, with reference to the 0.05 probability level, using SPSS software version 21. Data expressed as percentages were subjected to angular transformation before processing.

\section{Conclusions}

The results of the present investigation provide the first information regarding chervil Se and I biofortification efficiency with and without foliar nano-Si supply, emphasizing the high benefits of foliar nano-Si application for increasing I concentration and improving plant yield. Foliar nano-Si supplementation to chervil plants produced the following effects, compared to the single Se and I treatments: (i) Enhanced photosynthetic pigment production; (ii) Decreased nitrate and $\mathrm{Na}^{+}$contents; (iii) Restored $\mathrm{Fe}, \mathrm{Mn}$ and $\mathrm{Cr}$ accumulation. $\mathrm{Al}$ content was also increased by foliar nano-Si application under $\mathrm{Se}+\mathrm{I}$ biofortification. Considering the high variability of the $\mathrm{Si}$ effect on different plant species, further studies will be planned to unveil the general prospects of both soil nano-Si application for strengthening plant Se/I biofortification, and foliar nano-Si effect on Se/I biofortification of other agricultural crops.

Supplementary Materials: The following are available online at https://www.mdpi.com/article/ 10.3390/plants10112528/s1, Table S1: Coefficients of correlation between mineral elements in chervil shoots.

Author Contributions: Experiment conceptualization: N.G., H.K. and A.M.; silicon nanoparticles production and characteristics provision: M.F., G.F. and A.A.; field experiment management and determinations: V.K. and N.G.; laboratory determinations: N.G., H.K. and A.M.; data statistical processing: N.G., H.K. and G.C.; data interpretation, and draft and final-version manuscript writing: N.G., H.K., A.M., M.F., G.F., A.A., V.K. and G.C.; All authors have read and agreed to the published version of the manuscript.

Funding: This research did not receive any grants from public, commercial, or not-for-profit agencies.

Data Availability Statement: Not applicable.

Conflicts of Interest: The authors declare that they have no conflict of interest.

\section{References}

1. Golubkina, N.; Moldovan, A.; Kekina, H.; Kharchenko, V.; Sekara, A.; Vasileva, V.; Skrypnik, L.; Tallarita, A.; Caruso, G. Joint Biofortification of Plants with Iodine and Selenium: A New Field of Discoveries. Plants 2021, 10, 1352. [CrossRef]

2. Golubkina, N.; Papazyan, T. Selenium in Nutrition. Plants, Animals, Human beings-Moscow; Pechatny Gorod: Yekaterinburg, Russia, 2006. (In Russian)

3. Rayman, M.P. The importance of Se to human health. Lancet 2000, 356, 233-241. [CrossRef]

4. World Health Organization. Assessment of Iodine Deficiency Disorders and Monitoring Their Elimination: A Guide for Programme Managers; WHO: Geneva, Switzerland, 2007.

5. Zimmermann, M.B. The role of iodine in human growth and development. Semin. Cell Dev. Biol. 2011, 22, 645-652. [CrossRef] [PubMed]

6. Bilal, M.Y.; Dambaeva, S.; Kwak-Kim, J.; Gilman-Sachs, A.; Beaman, K.D. A Role for Iodide and Thyroglobulin in Modulating the Function of Human Immune Cells. Front. Immunol. 2017, 8, 1573. [CrossRef]

7. World Health Organization. Vitamin and Mineral Requirements in Human Nutrition; Report of a Joint FAO/WHO Expert Consultation; WHO: Bangkok, Tailand; Geneva, Switzerland, 2004. 
8. Alfthan, G.; Eurola, M.; Ekholm, P.; Venäläinen, E.R.; Root, T.; Korkalainen, K.; Hartikainen, H.; Salminen, P.; Hietaniemi, V.; Aspila, P.; et al. Effects of nationwide addition of selenium to fertilizers on foods, and animal and human health in Finland: From deficiency to optimal selenium status of the population. J. Trace Elem. Med. Biol. 2015, 31, 142-147. [CrossRef]

9. Smolen, S.; Kowalska, I.; Halka, M.; Ledwozyw-Smolen, I.; Grzanka, M.; Skoczylas, Ł.; Czernicka, M.; Pitala, J. Selected Aspects of Iodate and Iodosalicylate Metabolism in Lettuce Including the Activity of Vanadium Dependent Haloperoxidases as Affected by Exogenous Vanadium. Agronomy 2020, 10, 1. [CrossRef]

10. Golubkina, N.; Gomez, L.; Kekina, H.; Hallam, R.; Tallarita, A.; Cozzolino, E.; Torino, V.; Koshevarov, A.; Cuciniello, A.; Maiello, R.; et al. Joint Selenium-iodine Supply and Arbuscular Mycorrhizal Fungi Inoculation Affect Yield and Quality of Chickpea Seeds and Residual Biomass. Plants 2020, 9, 804. [CrossRef]

11. Smolen, S.; Wierzbínska, J.; Sady, W.; Kołton, A.; Wiszniewska, A.; Liszka-Skoczylas, M. Iodine biofortification with additional application of salicylic acid affects yield and selected parameters of chemical composition of tomato fruits (Solanum lycopersicum L.). Sci. Hortic. 2015, 188, 89-96. [CrossRef]

12. Badawy, S.A.; Zayed, B.A.; Bassiouni, S.M.A.; Mahdi, A.H.A.; Majrashi, A.; Ali, E.F.; Seleiman, M.F. Influence of Nano Silicon and Nano Selenium on Root Characters, Growth, Ion Selectivity, Yield, and Yield Components of Rice (Oryza sativa L.) under Salinity Conditions. Plants 2021, 10, 1657. [CrossRef]

13. Rajput, V.D.; Minkina, T.; Feizi, M.; Kumari, A.; Khan, M.; Mandzhieva, S.; Sushkova, S.; El-Ramady, H.; Verma, K.K.; Singh, A.; et al. Effects of Silicon and Silicon-Based Nanoparticles on Rhizosphere Microbiome, Plant Stress and Growth. Biology 2021, 10, 791. [CrossRef]

14. Verma, K.K.; Song, X.-P.; Li, D.-M.; Singh, M.; Rajput, V.D.; Malviya, M.K.; Minkina, T.; Singh, R.K.; Singh, P.; Li, Y.-R. Interactive Role of Silicon and Plant-Rhizobacteria Mitigating Abiotic Stresses: A New Approach for Sustainable Agriculture and Climate Change. Plants 2020, 9, 1055. [CrossRef] [PubMed]

15. Chen, D.; Wang, S.; Yin, L.; Deng, X. How Does Silicon Mediate Plant Water Uptake and Loss Under Water Deficiency? Front. Plant Sci. 2018, 9, 281. [CrossRef] [PubMed]

16. Kleiber, T.; Borowiak, K.; Kosiada, T.; Breś, W.; Ławniczak, B. Application of selenium and silicon to alleviate short-term drought stress in French marigold (Tagetes patula L.) as a model plant species. Open Chem. 2020, 18, 1468-1480. [CrossRef]

17. Shalaby, T.A.; Abd-Alkarim, E.; El-Aidy, F.; El-Samahy, H.; Sharaf-Eldin, M.; Taha, N.; El-Ramady, H.; Bayoumi, Y.; Reis, A.R. Nano-selenium, silicon and $\mathrm{H}_{2} \mathrm{O}_{2}$ boost growth and productivity of cucumber under combined salinity and heat stress. Ecotoxicol. Environ. Saf. 2021, 212, 111962. [CrossRef] [PubMed]

18. Zahedi, S.M.; Moharrami, F.; Sarikhani, S.; Padervand, M. Selenium and silica nanostructure-based recovery of strawberry plants subjected to drought stress. Sci. Rep. 2021, 10, 17672. [CrossRef]

19. Guo, K.; Hu, A.; Wang, K.; Wang, L.; Fu, D.; Hao, Y.; Wang, Y.; Ali, A.; Adeel, M.; Rui, Y.; et al. Effects of spraying nano-materials on the absorption of metal(loid)s in cucumber. IET Nanobiotechnol. 2019, 13, 712-719. [CrossRef]

20. Le, V.N.; Rui, Y.; Gui, X.; Li, X.; Liu, S.; Han, Y. Uptake, transport, distribution and Bio-effects of $\mathrm{SiO}_{2}$ nanoparticles in Bt-transgenic cotton. J. Nanobiotechnol. 2014, 12, 50. [CrossRef]

21. Attia, E.A.; Elhawat, N. Combined foliar and soil application of silica nanoparticles enhances the growth, flowering period and flower characteristics of marigold (Tagetes erecta L.). Sci. Hortic. 2021, 282, 110015. [CrossRef]

22. Rastogi, A.; Tripathi, D.K.; Yadav, S.; Chauhan, D.K.; Zivcak, M.; Ghorbanpour, M.; El-Sheery, N.I.; Brestic, M. Application of silicon nanoparticles in agriculture. 3 Biotech 2019, 9, 90. [CrossRef]

23. Pavlovic, J.; Kostic, L.; Bosnic, P.; Kirkby, E.A.; Nikolic, M. Interactions of Silicon with Essential and Beneficial Elements in Plants. Front. Plant Sci. 2021, 12, 697592. [CrossRef]

24. Kharchenko, V.A.; Moldovan, A.I.; Golubkina, N.A.; Gins, M.S.; Shafigullin, D.R. Comparative evaluation of several biologically active compounds content in Anthriscus sylvestris (L.) Hoffm. and Anthriscus cerefolium (L.) Hoffm. Veg. Crop. Russ. 2020, 5, 81-87. (In Russian) [CrossRef]

25. Ligowe, I.S.; Bailey, E.H.; Young, S.D.; Ander, E.L.; Kabambe, V.; Chilimba, A.D.; Lark, R.M.; Nalivata, P.C. Agronomic iodine biofortification of leafy vegetables grown in Vertisols, Oxisols and Alfisols. Environ. Geochem. Health 2021, 43, 361-374. [CrossRef] [PubMed]

26. Schiavon, M.; Nardi, S.; Dalla Vecchia, F.; Ertani, A. Selenium biofortification in the 21st century: Status and challenges for healthy human nutrition. Plant Soil 2020, 453, 245-270. [CrossRef]

27. Kharchenko, V.A.; Golubkina, N.A.; Moldovan, A.I.; Caruso, G. Biofortification of chervil with selenium. Veg. Crop. Russ. 2021, 1, 3-7. (In Russian) [CrossRef]

28. Gupta, M.; Gupta, S. An Overview of Selenium Uptake, Metabolism, and Toxicity in Plants. Front. Plant Sci. 2017, 7, 2074. [CrossRef]

29. Kiferle, C.; Martinelli, M.; Salzano, A.M.; Gonzali, S.; Beltrami, S.; Salvadori, P.A.; Hora, K.; Holwerda, H.T.; Scaloni, A.; Perata, P. Evidences for a Nutritional Role of Iodine in Plants. Front. Plant Sci. 2021, 12, 616868. [CrossRef]

30. Coskun, D.; Deshmukh, R.; Sonah, H.; Menzies, J.G.; Reynolds, O.; Ma, J.F.; Kronzucker, H.J.; Belanger, R.R. The controversies of silicon's role in plant biology. New Phytol. 2019, 221, 67-85. [CrossRef]

31. Greger, M.; Landberg, T.; Vaculík, M. Silicon influences soil availability and accumulation of mineral nutrients in various plant species. Plants 2018, 7, 41. [CrossRef] 
32. Janmohammadi, M.; Amanzadeh, T.; Sabaghnia, N.; Ion, V. Effect of nano-silicon foliar application on safflower growth under organic and inorganic fertilizer regimes. Bot. Lith. 2016, 22, 53-64. [CrossRef]

33. Strzetelski, P.; Smolen, S.; Rozek, S.; Sady, W. The effect of diverse iodine fertilization on nitrate accumulation and content of selected compounds in radish plants (Raphanus sativus L.). Acta Sci. Pol. Hortorum Cultus 2010, 9, 65-73.

34. Rios, J.J.; Blasco, B.; Rosales, M.A.; Sanchez-Rodriguez, E.; Leyva, L.; Cervilla, L.M.; Romera, L.; Ruiz, J.M. Response of nitrogen metabolism in lettuce plants subjected to different doses and forms of selenium. J. Sci. Food Agric. 2010, 90, 1914-1919. [CrossRef]

35. Detmann, K.C.; Araujo, W.L.; Martins, S.C.; Sanglard, L.M.; Reis, J.V.; Detmann, E.; Rodrigues, F.Á.; Nunes-Nesi, A.; Fernie, A.R.; DaMatta, F.M. Silicon nutrition increases grain yield, which, in turn, exerts a feed-forward stimulation of photosynthetic rates via enhanced mesophyll conductance and alters primary metabolism in rice. New Phytol. 2012, 196, 752-762. [CrossRef]

36. Wu, X.; Yu, Y.; Baerson, S.R.; Song, Y.; Liang, G.; Ding, C.; Niu, J.; Pan, Z.; Zeng, R. Interactions between nitrogen and silicon in rice and their effects on resistance toward the brown planthopper Nilaparvata lugens. Front. Plant Sci. 2017, 8, 28. [CrossRef]

37. Haddad, C.; Arkoun, M.; Jamois, F.; Schwarzenberg, A.; Yvin, J.C.; Etienne, P.; Laîné, P. Silicon promotes growth of Brassica napus L. and delays leaf senescence induced by nitrogen starvation. Front. Plant Sci. 2018, 9, 516. [CrossRef]

38. Gou, T.; Yang, L.; Hu, W.; Chen, X.; Zhu, Y.; Guo, J.; Gong, H. Silicon improves the growth of cucumber under excess nitrate stress by enhancing nitrogen assimilation and chlorophyll synthesis. Plant Physiol. Biochem. 2020, 152, 53-61. [CrossRef] [PubMed]

39. Luyckx, M.; Hausman, J.-F.; Lutts, S.; Guerriero, G. Silicon and Plants: Current Knowledge and Technological Perspectives. Front. Plant Sci. 2017, 8, 411. [CrossRef]

40. Dobosy, P.; Vetési, V.; Sandil, S.; Endrédi, A.; Kröpfl, K.; Óvári, M.; Takács, T.; Rékási, M.; Záray, G. Effect of Irrigation Water Containing Iodine on Plant Physiological Processes and Elemental Concentrations of Cabbage (Brassica oleracea L. var. capitata L.) and Tomato (Solanum lycopersicum L.) Cultivated in Different Soils. Agronomy 2020, 10, 720. [CrossRef]

41. Incrocci, L.; Carmassi, G.; Maggini, R.; Poli, C.; Saidov, D.; Tamburini, C.; Kiferle, C.; Perata, P.; Pardossi, A. Iodine Accumulation and Tolerance in Sweet Basil (Ocimum basilicum L.) with Green or Purple Leaves Grown in Floating System Technique. Front. Plant Sci. 2019, 10, 1494. [CrossRef] [PubMed]

42. Golubkina, N.; Kekina, H.; Caruso, G. Yield, quality and antioxidant properties of Indian mustard (Brassica juncea L.) in response to foliar biofortification with selenium and iodine. Plants 2018, 7, 80. [CrossRef]

43. Bhat, J.A.; Rajora, N.; Raturi, G.; Sharma, S.; Dhiman, P.; Sanand, S.; Shivaraj, S.M.; Sonah, H.; Deshmukh, R. Silicon nanoparticles (SiNPs) in sustainable agriculture: Major emphasis on the practicality, efficacy and concerns. Nanoscale Adv. 2021, 3, 4019-4028. [CrossRef]

44. Krzepiłko, A.; Zych-Wężyk, I.; Święciło, A.; Molas, J.; Skwaryło-Bednarz, B. Effect of iodine biofortification of lettuce seedlings on their mineral composition and biological quality. J. Elem. 2016, 21, 1071-1080. [CrossRef]

45. Sattara, A.; Cheema, M.A.; Abbas, T.; Sher, A.; Ijaz, M.; Hussain, M. Separate and Combined Effects of Silicon and Selenium on Salt Tolerance of Wheat Plants. Russ. J. Plant Physiol. 2017, 64, 341-348. [CrossRef]

46. Macías, J.M.; Caltzontzit, M.G.L.; Martínez, E.N.R.; Ortiz, W.A.N.; Mendoza, A.B.; Lagunes, P.M. Enhancement to Salt Stress Tolerance in Strawberry Plants by Iodine Products Application. Agronomy 2021, 11, 602. [CrossRef]

47. Almeida, D.M.; Oliveira, M.M.; Saibo, N.J.M. Regulation of $\mathrm{Na}^{+}$and $\mathrm{K}^{+}$homeostasis in plants: Towards improved salt stress tolerance in crop plants. Genet. Mol. Biol. 2017, 40, 326-345. [CrossRef] [PubMed]

48. Siddiqui, M.H.; Al-Whaibi, M.H.; Faisal, M.; Al Sahli, A.A. Nano-silicon dioxide mitigates the adverse effects of salt stress on Cucurbita pepo L. Environ. Toxicol. Chem. 2014, 33, 2429-2437. [CrossRef]

49. Abdel-Haliem, M.E.F.; Hegazy, H.S.; Hassan, N.S.; Naguib, D.M. Effect of silica ions and nano silica on rice plants under salinity stress. Ecol. Eng. 2017, 99, 282-289. [CrossRef]

50. Zhu, Y.-X.; Gong, H.-J.; Yin, J.-L. Role of Silicon in Mediating Salt Tolerance in Plants: A Review. Plants 2019, 8, 147. [CrossRef]

51. Medrano-Macías, J.; Leija-Martínez, P.; González-Morales, S.; Juárez-Maldonado, A.; Benavides-Mendoza, A. Use of Iodine to Biofortify and Promote Growth and Stress Tolerance in Crops. Front. Plant Sci. 2016, 7, 1146. [CrossRef]

52. Zhou, X.; Yang, J.; Kronzucker, H.J.; Shi, W. Selenium Biofortification and Interaction with other elements in plants: A Review. Front. Plant Sci. 2020, 11, 586421. [CrossRef] [PubMed]

53. Golubkina, N.; Zamana, S.; Seredin, T.; Poluboyarinov, P.; Sokolov, S.; Baranova, H.; Krivenkov, L.; Pietrantonio, L.; Caruso, G. Effect of selenium biofortification and beneficial microorganism inoculation on yield, quality and antioxidant properties of shallot bulbs. Plants 2019, 8, 102. [CrossRef]

54. Golubkina, N.; Amagova, Z.; Matsadze, V.; Caruso, G. Effects of arbuscular mycorrhizal fungi on yield, biochemical characteristics and elemental composition of garlic and onion under selenium supply. Plants 2020, 9, 84. [CrossRef]

55. Wang, S.; Wang, F.Y.; Gao, S. Foliar application with nano-silicon alleviates Cd toxicity in rice seedlings. Environ. Sci. Pollut. Res. 2014, 22, 2837-2845. [CrossRef]

56. Feng, R.W.; Zhao, P.P.; Zhu, Y.M.; Yang, J.G.; Wei, X.Q.; Yang, L.; Yan, H.; Rensing, C.; Ding, Y.Z. Application of inorganic selenium to reduce accumulation and toxicity of heavy metals (metalloids) in plants: The main mechanisms, concerns, and risks. Sci. Total Environ. 2021, 771, 144776. [CrossRef]

57. Zhou, P.; Adeel, M.; Shakoor, N.; Guo, M.; Hao, Y.; Azeem, I.; Li, M.; Liu, M.; Rui, Y. Application of Nanoparticles Alleviates Heavy Metals Stress and Promotes Plant Growth: An Overview. Nanomaterials 2021, 11, 26. [CrossRef] [PubMed]

58. Lichtenthaler, H.K. Chlorophylls and carotenoids: Pigments of photosynthetic biomembranes. Methods Enzymol. 1987, 148, $350-382$. 
59. Golubkina, N.A.; Kekina, H.G.; Molchanova, A.V.; Antoshkina, M.S.; Nadezhkin, S.M.; Soldatenko, A.V. Plants Antioxidants and Methods of Their Determination. Infra-M Mosc. Russ. 2020, 181. [CrossRef]

60. Baranov, V.I.; Soldatenkova, N.A.; Kekina, H.G. Iodine determination in marine products using inversion voltamperometry. Hyg. Sanit. 2008, 3, 35-37. (In Russian)

61. Skalny, A.V.; Lakarova, H.V.; Kuznetsov, V.V.; Skalnaya, M.G. Analytical Methods in Bioelementology; Saint Petersburg-Science: St. Petersburg, Russia, 2009. (In Russian)

62. Alfthan, G.V. A micromethod for the determination of selenium in tissues and biological fluids by single-test-tube fluorimetry. Anal. Chim. Acta 1984, 165, 187-194. [CrossRef] 